\title{
What Did Our Ancestors Eat?
}

\author{
Stanley M. Garn, Ph.D., and William R. Leonard, Ph.D.
}

Over the millennia various hominoids and hominids have subsisted on very different dietaries, depending on climate, hunting proficiency, food-processing technology, and available foods. The Australopithecines were not browsers and fruit-eaters with very high intakes of vitamin C; rather they were scavengers of kills made by other animals. The hominids who followed did include some cold-climate hunters of large game, but the amount of animal protein decreased with the advent of grain-gathering and decreased further with the introduction of cereal agriculture, with a concomitant decrease in body size. From what we know about food adequacy, preparation, and storage, the notion that the postulated "primitive" diet was generally adequate, safe, and prudent can be rejected. Over evolutionary time, many of our ancestors ate poorly, especially during climatic extremes, and they were often at risk for vitamin deficiencies, food-borne diseases, and neurotoxins. Until the advent of modern processing technologies, dirt, grit, and fiber constituted a large part of most early diets.

Key Words: primitive diet, fossil humans, hominids, hominoids, fat, protein, fiber, nutritional deficiency, food safety

It is a reasonable notion, consistent with the tenets of evolutionary biology, that the nutritional requirements and dietary needs of contemporary human beings were established in the prehistoric past. It follows that some dietary practices that may be "unhealthy" for contemporary human beings are disadvantageous because we are not adapted to such nutrient excesses or deficiencies. For these reasons we now witness considerable interest in what our ancestors ate and various attempted reconstructions of the beneficial "diets" our ancestors presumably enjoyed. ${ }^{1}$ Inferences as to the diets of fossil hominids and fossil hominoids are equally cited by advocates of megavitamin therapy, by those who urge increased consumption of nondigestible

Dr. Garn is Professor of Nutrition and Anthropology, University of Michigan, Ann Arbor, MI. Dr. Leonard is Assistant Professor, School of Human Biology, University of Guelph, Guelph, Ontario, Canada. fibers, and by advocates of a high-protein dietary regimen.

Some workers in human nutrition see us as the descendants of foraging and browsing and fruit-eating ancestors, with a diet necessarily high in ascorbic acid. Thus Tobian $^{2}$ wrote, "prehistoric humans and hominids ... lived as pure hunter-gatherers and ate only the natural food that could be obtained from hunting or collecting vegetable materials such as roots, fruits, tubers, nuts, grains, and seeds." Others working in the field of human nutrition view contemporary mankind as the recent descendants of animal-hunting, flesh-eating ancestors of the ice age, like the classic Neanderthals or the polar Eskimo. In consequence they view a daily intake of $1 \mathrm{~g}$ of quality protein $/ \mathrm{kg}$ of body weight as far too low, even though it sustains life and allows growth. Still others draw attention to the presumed seed-eaters of our most distant past, or grubbers and gatherers still extant, with diets high in insoluble fiber and stool volumes of remarkable size.

These various dietary models cover a very considerable period in evolutionary time. For the gorilla-like browsing and foraging model, one must assign a time depth 
of 5-8 million years, before Homo and Gorilla and Pan diverged, according to DNA sequence calculations. That is a long time ago, and we may have made many dietary and nutritional adaptations in the interim. For the presumably seed-eating ancestral model, hominoids but not necessarily hominids, a time depth of 1-2 million years is now tenable, if we assume that they were our ancestors. For the animal-hunting, cold-climate Neanderthals, who were of our genus and even of our species, we assume a time depth of 50,000 years into the late Pleistocene. These are very different models and very different taxa, even assuming that they are all in our direct ancestral line. In the Holocene, i.e., the recent postglacial period, there have been ever so many groups of human beings, subsisting on very different dietaries. Now we ask, 'Which are our 'ancestors' and what did they eat?"

Because our early ancestors lived before the days of commercial food processing and before the addition of preservatives, coloring agents, extenders, and antioxidants, their diets have been described as "simple," "natural," and "safe." Their dietaries, presumably of mixed animal and vegetable origin, have also been described as "prudent," a term of recent introduction. However, it is probable that pit-stored and pot-stored grains may not have been safe, under all circumstances, nor were animal flesh and fish eaten by early humans free of parasites. Caloric adequacy cannot be presumed in all seasons, for all mankind, nor can we assume the postulated "dietary prudence" with respect to animal fats or vitamins $A$ and $C$.

In theory, fossil dentitions should provide insight into dietary habits (and therefore the kinds of foods and their volume). In a way this theory is true, since the hominoids and early hominids had larger dental arcades than we do and far larger food-processing surfaces. However, even the erectus fossils did not have long, projecting gorilla-like canines or the highly convoluted wrinkled molar surfaces that suggest dependence on roots, shoots, and large leaves. Our dentitions now are at most indicative of an omnivorous but relatively soft diet and they are equally suitable for gnawing at bones, gorging on fruit, or consuming fried rice, boiled wheat, and unleavened cakes. However, and despite their more specialized dentitions, chimpanzees prove to be far more omnivorous in the wild than we had earlier reason to imagine. ${ }^{3}$ So we must turn to the faunal and floral remains associated with past hominids and hominoids to provide some partial answers.

\section{Hominoids, Hominids, and Their Diets}

The Australopithecines, from South Africa, were once viewed as proto-hominid hunters of game because of the animal bones found at some of their habitation sites. ${ }^{4}$ Now they are relegated to the status of scavengers, who dragged other kills back home and deposited the remains in rather untidy fashion. Moreover, studies of the microwear on their dentitions suggest a wide utilization of available foods, attested to by the scratches and abrasions on their dental enamel. ${ }^{5-9}$

There were several kinds of Australopithecines, the larger and more robust forms (Australopithecus robustus in some taxonomies) and the smaller and more gracile kinds (Australopithecus africanus). The number of different Australopithecine genera and species is unknown, for they lived during a long period of rapid evolutionary change when species multiplied. Exactly which was most nearly ancestral to us is still a matter of reasonable debate, but some had unusually large brain size relative to body size and merged nicely into erectus proportions. They were erect-walking, unlike earlier primates, and had some capacity to use or fashion tools.

The Australopithecine diet can best be described as mixed, certainly impressing a heavy chewing load on their large dentitions and oversized dentofacial complexes. However, these hominids were not hunters but spent much of their time in search of food, including carcasses left by true predators. As "ancestors" they were much 
more recent than the chimpanzee-like ancestor of 5 million or more years ago and more nearly omnivorous. They certainly had the ability to masticate and digest a large variety of foods, and had a goodly proportion of grit in their diets. ${ }^{8-10}$ Inferences as to the Australopithecine diet come from observations of scavenging among modern hunter-gatherers and nonhuman primates ${ }^{11,12}$ and from analyses of animal bone assemblages found associated with early hominoid findings. ${ }^{13-15}$

\section{Our Genus But Not Our Species}

Next in order of appearance, in physical characteristics and in relationships to us, came the erectus fossils of our genus but not of our species, which we first came to know as "Pithecanthropus" from Java. The time frame for Homo erectus is early Pleistocene, the original habit of erectus was Africa, and the physical appearance of these non-sapiens hominids was a composite of new and old. Below the neck they were nearly indistinguishable from us. Above the neck they had much larger brains than the Australopithecines, but their brain volume $(1100 \mathrm{cc})$ was less than ours. Their large dentitions exceed those of any living group of humans, and their teeth were attached to jaws of comparable size, with muscle attachments well up on the cranium. No wonder that DuBos, who discovered the skull cap of Pithecanthropus a century ago, was for years uncertain as to exactly what he had found.

Homo erectus was a hunter who used stone tools and had the ability to make fires and presumably to cook or roast in the flames or coals. We therefore grant the erectus fossils a considerable year-round supply of animal flesh, but we have no knowledge of how much vegetation was also dug, pulled, picked, or stripped. Wear on erectus dentitions, which is considerable, appears to have been heightened by grit in the diet; these observations suggest plant sources for much of the food and no great fastidiousness in dining.

Climatic data and faunal associations indicate that these earlier people of our genus were not browsers. They correspond to the notion of "early man" as hunters, at least in part, and their generous intakes of nonnutrient materials certainly included dirt and small gravel. It is only a guess as to whether they cooked or processed in any way whatever vegetation they collected. ${ }^{16-18}$

\section{Changing Diets of the Later Pleistocene}

By the late Pleistocene erectus hominids had become extinct and people of our species (Homo sapiens) made successive appearances. They brought with them increasingly sophisticated technologies and distinctively different dietaries, ultimately including stone-ground wild grains and presumably some sort of hoe-cakes baked on rocks or ashes.

The Neanderthals (named after a small valley or $T a l)$ were rather widely distributed-from Germany and France, eastward into Russia and the Middle East, and thence to North Africa. They were cold-climate hunters of large game and presumably subsisted primarily on game during the coldest periods. They were the mighty hunters we once imagined, although the extent of dependence on fruits and roots in season is still problematic. They were bigbrained hominids, often larger than we in brain size, and by no means were they devoid of the niceties of life, including (apparently) burial of the dead and the ability to care for the crippled and the elderly to a respectably advanced age. ${ }^{19}$

Their cooking techniques appear to have included "earth-ovens" (a German term) constructed rather like a barbecue pit or a Hawaiian luau or a New England clambake. ${ }^{20}$ The Neanderthals were not stooped, they had the ability to slow-cook tough meat to chewability, and they did subsist on a diet rather high in animal protein. We presume that vitamin $C$ may have been in short supply during the long, cold winters of the ice age.

After the Neanderthals, with or without genetic admixture, came the people of the Upper Paleolithic and the Mesolithic, people who would not have looked out of place 
at any professional gathering now. They hunted, though they sought small mammals more than did the Neanderthals; they dug and foraged and grubbed and picked berries. They also developed the capacity to gather wild grains by use of very serviceable wooden scythes set with little pointed flakes (microliths), thus taking advantage of the wild grains that ripened each summer. They ground these grains on stone grinding blocks, and presumably baked the coarse flour as cakes, scones, or unleavened bread.

These people of the Upper Pleistocene, and later those of the Mesolithic, were our immediate ancestors, no longer hunters exclusively and with whole-grain products and a variable amount of roots, fruits, leafy vegetables, and nuts in their diet. ${ }^{21,22}$ We must grant them a mixed diet, with animal fat providing a smaller proportion of their food energy than was probably true for the Neanderthals. They still lacked pottery and therefore the capacity to make gruel, or potage, but they may have employed stoneboiling (in animal skins) and may have made a kind of haggis (mixing meat products and cereal grains).

\section{Advent of Agriculture and Diminution in Size}

The advent of agriculture is lost in antiquity and so are the reasons why different groups took up the cultivation of roots, shoots, tubers, fruits, nuts, leafy vegetables, and seed grains. Since even before agriculture some wild grains were harvested with scythe and sickle and then sprouted close to habitation sites, it is reasonable to guess how formal grain-growing began. However, while the origins of agriculture are debated, the consequences are clear. Grain growing in particular allowed population expansion (in fact it demanded the cooperative behavior of entire groups). Villages, even towns, grew with the grain fields, allowing the emergence of administrators and demanding defense forces for protection. While the sizes of populations grew, in permanent habitation sites the size of individuals often became smaller, ${ }^{23,24}$ a point that merits amplification in this review.

Grains, in particular, could be stored, providing a food reserve from one harvest to the next and assuring a more constant energy reserve year-round. Grain growing and many other forms of agriculture necessitated the cooperative labor of men, women, and children to plant, to weed, to protect against animals, and then to gather, grind, and store. Children formed an important part of the labor force, at cost to their own growth, as is true in many parts of the world today.

American archaeologists, in particular, observe a diminution in body size associated with the advent of maize agriculture and further deteriorations coincident with its intensive cultivation. They cite such evidence as an apparent increase in the number of radio-opaque (Harris) lines seen in the skeletons, diminished thickness of compact (cortical) bone, and punctate markings on the skulls that may suggest iron-deficiency or diminished availability of vitamin $C .{ }^{25,26}$ There are also well-documented growth deficiencies, including protein-energy malnutrition, that stem from single-crop agriculture. We are aware of many problems of growth and reproduction that arise from the phytates in wheat and other grains, reducing the availability of iron and zinc. Sensitivity to wheat gluten is another problem, most prevalent now in Wales and Ireland. ${ }^{27}$

Of course, agriculture itself is not to blame, but rather the departure from a mixed diet derived from a variety of sources. ${ }^{28}$ However, intensive single-crop agriculture is a natural response to growing population sizes and limited land, especially where the climate allows several crops each year. The answer to "What did our ancestors eat?" may be mostly maize or mostly wheat or mostly barley or mostly yams or mostly manioc, each with its own nutritional limitations.

The advantage of agriculture is also the ability to store grain, legumes, or other seeds in pits or pots against future need. In many parts of the American Southwest a 
two-year reserve was considered necessary. However, pit-stored and pot-stored grains and legumes are subject to losses inflicted by insects and rodents. Furthermore, if such foods are improperly dried or exposed to unseasonable moisture, they are subject to fungal infestations and contamination by various toxins. Ergotism and aflatoxin-derived diseases are possible disadvantageous consequences of grain agriculture.

All of our great cultures or civilizations have come from an agricultural base. Some of us have been grain eaters for 10,000 years. Even today, few Americans gain nearly as much food energy from flesh and milk products as from processed grains. However, agriculture has had its price in diminished body size (until rather recently and in the more favored nations). For those of us of European, Middle Eastern, or Asiatic ancestry, our ancestors ate mostly grain. The potato was a very recent introduction in Europe, and the Potato Famine of the last century is a further lesson on the shortcomings of agricultural dependence on a single crop and on what happens when that crucial crop fails.

\section{Drought, Famine, and Cyclical Starvation}

Most readers of Nutrition Reviews are quite insulated against seasonal and cyclical variations in food availability and in the intakes of specific nutrients. Only fresh berries and some fruits may be temporarily absent from our stores, but we can replace them with frozen or canned varieties. We do not have to eat much more in winter to compensate for heat lost from our bodies, and (except for the gardeners among us) we do not exert more energy in seasonal food gathering or agricultural labor. We sow not, neither do we reap. However, third-world people still experience seasonal variations in food availability and in the intakes of specific nutrients, as did nearly all of our immediate ancestors and the hunting and gathering and foraging humans of the past. ${ }^{29}$

We readers of Nutrition Reviews are also well protected against cyclical variations in food availability due to drought, excessive rainfall, or occasional winter kill. Our foods come from many geographic areas, we import a surprisingly large proportion of our food, and our storage facilities hold a multiyear supply of grains. However, year-toyear differences in crop yields, recurrent dryness and floods, and extended runs of adverse weather make for precarious food supplies in much of the world as well as in our recent historic past. We recall crop failures in England, the "Little Ice Age" (which lasted until the mid-1800s), and the "Seven Lean Years" recounted in the Bible. Once verdant areas of the Southwest are now near-deserts. Arabia was once "Eden." Long-term changes in rainfall and temperature have affected all of our ancestors and their access to food.

When we report energy and nutrient intakes for any population, it is important also to record the season of the year. Highseason intakes may be double those of the low season. ${ }^{30}$ Some nutrients, particularly ascorbic acid and the carotenoids in temperate climates, may be in short supply during part of the year. A survey conducted in one season may not reflect dietary adequacy in another. Moreover, averaging seasonal samplings may not be enough. Growth and development are obviously most affected by seasonal lows, and the low-season intakes may directly determine the size attained. Fertility, too, may be seasonal and most affected by low-season availability of food. Fewer conceptuses will come to term or reach a viable birthweight if food is restricted in the later months of pregnancy. Most agricultural peoples experience such seasonal variations in food availability, and so do hunters and gatherers. Bushmen in Africa lose considerable weight and fat during the rainy season and regain both when dry weather returns and there are more plants to gather and use. American Indians who lived by the hunt experienced seasonal differences in weight and so did the animals they hunted. ${ }^{31}$ Tropical forests are not equally productive of fruits and roots the year round; these forests do not have everlasting summer. 
When we attempt to reconstruct the diets of hunters, hunter-gatherers, diggers, and foragers (hominid or hominoid), seasonal variations in food availability must be kept in mind, and so must seasonal and cyclical variations in fat weight or percentage fat and in the size of the lean body mass as well.

\section{Poorer and Richer}

In general, the more affluent or the politically favored had more access to food and were protected by rank, status, and wealth against seasonal variations in availability of food, especially animal fats and animal protein. Many recent studies, such as those in the Altiplana, ${ }^{31,32}$ document the much smaller seasonal variability in foods consumed by the more affluent and the greater cyclic disparity in foods available to the poor. Size and growth rates of the children, therefore, reflect the low-season intakes of the poor. Although we cannot project backwards over the entire history of humankind, such differences surely existed in predynastic Egypt, in Meso-America, and in Asia. Dimensional differences between the nobility and the peasants are obvious in European skeletal material and apparently reached their maximum in early Victorian times. Burial mounds from Illinois to Tennessee also indicate the nutritional advantages of higher social status. The rich or the nobles did get the gravy, even in the prehistoric Americas.

The question of what our ancestors ate, therefore, represents more than just the level of food technology and the shift to food production rather than food gathering. ${ }^{33}$ Seasonal variations must be considered, including the length of the low season and the extent to which available resources were diminished. Human beings must have adapted, albeit imperfectly, to low-season dietary and nutritional deficits. Longer-term food restrictions, of climatic origin, must have had a major impact on the elderly, on the young, and on pregnant women. Moreover, we cannot assume that most populations were strictly egalitarian, allotting unto each according to his nutri- tional needs. By right of birth, accomplishment, or valor some were accorded an extra share (or took it by force). Some men had multiple wives, a custom allowing longer birth-spacing and therefore more viable progeny, each more likely to survive.

Our ancestors' diet, therefore, is not just a function of evolutionary time and of whether they hunted or gathered or planted, or whether they ate seeds or tubers or game, but also is a function of differences in food availability ${ }^{34}$ and of the duration of droughts and famines. Moreover, what the Neanderthals or the Australopithecines ate may be less relevant to our requirements than what was eaten in ancient Anatolia, Thessaly, Indonesia, the European city-states, or medieval towns. For some of us at least, when our ancestors acquired wheat instead of oats or barley may be far more relevant than whether we are most directly descended from hunters or gatherers or scavengers or whether we trace our ancestry to browsers and fruit eaters in some Miocene tropical forest. ${ }^{35}$

\section{What Natural, Healthy, or "Prudent" Diet?}

So far in this review we have made no attempt to estimate the energy intakes or nutrient densities of any of the hominoids or hominids of the past, although we emphasized their very different probable dietaries. Even for the Neanderthal hunters of the late Pleistocene, who subsisted on a highprotein diet out of necessity, the amount of seasonal energy supplied by carbohydrates is conjectural, as is that supplied by animal fats. The game was lean by contemporary standards of the U.S. Department of Agriculture, but we do not know whether the Neanderthals gorged on the fat or trimmed it off. Eaton and Konner ${ }^{1}$ have published some estimates of the fossil diet, having decided first upon an arbitrary energy intake and then having assigned a "mixed" diet including fruits, flesh, and leaves. Not surprisingly, they then deemed their "primitive" diet both adequate and "healthy."

Obviously, most of the time (excluding famines, shortages, and off-season lows), the energy intake at most periods in the 
past was sufficient for growth and reproduction. Whether the energy intake at most past periods approximated the larger recommendations of the U.S. National Academy of Sciences or the smaller ones of the World Health Organization is uncertain, especially for the agriculturalists and for those practicing single-cereal agriculture. However, none of the evidence from the early Pleistocene onward suggests extremely high intakes of vitamin $C$. Of course, most of the taxa mentioned ingested more nondigestible fibers than we do, and far more grit and ashes too.

How past dietaries bore on chronic and debilitating diseases is conjectural, given the abbreviated lengths of life. So we cannot assume that Australopithecines were free of colorectal cancer or that the people of the Mesolithic did not suffer from hypertension. Calcium intakes may have been low for the massive meat eaters, unless they chewed bones and ate fish whole. They may also have experienced symptoms of scurvy in the late winter; we know that the hunters of the North American plains showed signs of vitamin C deficiency.

The safety of the diets of our early ancestors is a further question, given animal parasites (and insufficient cooking), toxins resulting from poor storage of food, cycad neurotoxins, toxins and neurotoxins resulting from inadequate preparation of food, and the occasional inclusion of toxic plants mixed with those gathered in the wild. For the early miners of metals, ochre, and other pigments, heavy metal contaminations were an occupational hazard. Shellfish eaters of the past also had to contend with "red tides."

Although we think of early man as accustomed to a low-sodium intake, at least inland and at higher elevations, salt springs, salt outcroppings, and salt caves were discovered by human beings early and were exploited or mined for millennia. Salzburg, Salt Lick, and Salts Cave remain as place names, to remind us of their original functions. Salts Cave in Kentucky provided Glaubers' salt (sodium sulfate), a remedy for constipation. Sea salt entered into trade channels early in the Neolithic and was traded hundreds of miles inland. Though wood ashes served as a low-sodium and high-potassium condiment for the Indians of the Southwest, some of our cultivated plants, including beets and carrots, do provide as much as $200 \mathrm{mg}$ of sodium per edible portion. Some of our ancestors may have had a considerable sodium intake, even before salt was regularly used for the preservation of fish and meats.

It is part of our intellectual tradition to romanticize the past, both so-called Natural Man and an imaginary time in the past when people were presumably healthy and happy subsisting on unprocessed foods. Ever so many food regimens, including that suggested by Graham (of Graham cracker fame) and the natural-food regimen developed by Dr. Kellogg of the Battle Creek Sanatorium, have been hailed as a return to our early diets. In reviewing what we know about our ancestors of the more recent and more distant past, it is difficult to identify any one dietary that may represent our specific adaptation. In length of time, measured in millions of years, the diet of the scavenging Australopithecines may perhaps be designated as ours; it is a highfiber diet, for sure. For most of us, originating in Europe or Asia, a diet high in carbohydrate and grain phytates (but low in animal protein and animal fat) may be the diet to which we had become accustomed, though not necessarily adapted. Except for the polar Eskimo, a diet high in animal fat is not in our gastrointestinal tradition, nor, except for the Aleut and Indians of the Northwest, is a diet high in fish oils with salmon at every meal.

Past foods may have been unprocessed and free from pesticides and additives, but they were not necessarily safe, before or after cooking. Parasites lurked in undercooked meats, fungal infestations contaminated grains in the fields and during storage, heavy metals leached out of decorated pottery, cooked legumes held their own dangers, and cyanides remained in poorly processed tubers. While our immediate ancestors were not exposed to cycad toxicity 
and its long-term neurologic consequences, they did not always enjoy enough food, an adequate protein intake, or reasonable levels of many vitamins the yearround. However, we can grant them a higher intake of fiber, with possible consequences to calcium availability and protein utilization.

1. Eaton SB, Konner M. Paleolithic nutrition: a consideration of its nature and current implications. N Engl J Med 1985;312:283-9

2. Tobian L. Potassium and hypertension. Nutr Rev 1988;46:273-83

3. Teleki G. The omnivorous diet and eclectic feeding habits of chimpanzees in Gombe National Park, Tanzania. In: Harding RSO, Teleki G, eds. Omnivorous primates. New York: Columbia University Press, 1981:303-43

4. Potts R, Shipman P. Cutmarks made by stone tools on bones from Olduvai Gorge, Tanzania. Nature 1981;291:577-80

5. Robinson JT. Adaptive radiation in the australopithecines and the origin of man. In: Howell FC, ed. African ecology and human evolution. Chicago: Aldine, 1963:385-416

6 . Jolly $\mathrm{CJ}$. The seed-eaters: a new model of hominid differentiation based on a baboon analogy. Man 1970;5:5-26

7. Wolpoff MH. Posterior tooth size, body size, and diet in South African gracile australopithecines. Am J Phys Anthropol 1973;39:375-94

8. Grine FE. Trophic differences between gracile and robust australopithecines: a scanning electron microscope analysis of occlusal events. $S$ Afr J Sci 1981;77:203-30

9. Ryan AS. Anterior dental microwear in hominid evolution: a comparison with human and nonhuman primates [dissertation]. Ann Arbor, MI: University of Michigan, 1980

10. Walker A. Diet and teeth: dietary hypotheses and human evolution. Phil Trans $R$ Soc Lond [B] 1981;292:57-64

11. Strum SC. Processes and products of change: baboon predatory behavior. In: Harding RSO, Teleki G, eds. Omnivorous primates. New York: Columbia University Press, 1981:255-302

12. Ardrey RA. African genesis. New York: Atheneum Press, 1961

13. Bunn $H$. Archeological evidence for meat-eating by Plio-Pleistocene hominids from Koobi Fora and Olduvai Gorge. Nature 1981;291:574-7

14. Washburn SL, Lancaster CS. The evolution of hunting. In: Lee RB, DeVore I, eds. Man the hunter. Chicago: Aldine, 1968:293-303

15. Shipman P. Scavenging or hunting in early hominids: theoretical framework and tests. Am Anthropol 1986;88:27-43

16. Wolpoff $\mathrm{MH}$. Paleoanthropology. New York: Alfred A. Knopf, 1980

17. Wolpoff $\mathrm{MH}$. Evolution in Homo erectus: the question of stasis. Paleobiology 1984;10:389406

18. Brown F, Harris J, Leakey R, Walker A. Early Homo erectus skeleton from west Lake Turkana Kenya. Nature 1985;316:788-92

19. Brace CL. Krapina, "classic" Neanderthals, and the evolution of the European face. J Hum Evol $1979 ; 8: 527-50$

20. Brace $C_{L}$, Rosenberg $K R$, Hunt $K D$. Gradual change in human tooth size in the late Pleistocene and post-Pleistocene. Evolution 1987; 41:705-20

21. Freeman LG. The fat of the land: notes on the paleolithic diet in Iberia. In: Harding RSO, Teleki $\mathrm{G}$, eds. Omnivorous primates. New York: Columbia University Press, 1981:104-65

22. Klein RG. Later stone age subsistence at Byeneskranskop Cave, South Africa. In: Harding RSO, Teleki $G$, eds. Omnivorous primates. New York: Columbia University Press, 1981:166-90

23. Cohen MN. Toward a theory of human food habits: the significance of long-term changes in human diet and food economy. In: Harris M, Ross EB, eds. Food and evolution: toward a theory of human food habits. Philadelphia: Temple University Press, 1987:166-90

24. Cohen MN, Armelagos GJ, eds. Paleopathology at the origins of agriculture. New York: Academic Press, 1984

25. Buikstra JE, Cook DC. Paleopathology: an American account. Annu Rev Anthropol 1980;9:433-70

26. Goodman AH, Armelagos $G J$, Rose JC. The chronological distribution of enamel hypoplasias from prehistoric Dickson mounds populations. Am J Phys Anthropol 1984;65:259-66

27. Robinson $\mathrm{CH}$, Lawler MR, Chenoweth WL, Garwick AE. Normal and therapeutic nutrition. 17th ed. New York: MacMillan, 1986

28. Flannery KV. The origins of agriculture. Annu Rev Anthropol 1973;2:271-310

29. Harrison GA, ed. Famine. New York: Oxford University Press, 1988

30. Leonard WR, Thomas RB. Changing dietary patterns in the Peruvian Andes. Ecol Food Nutr $1988 ; 21: 245-63$

31. Speth JD, Davis DD. Seasonal variability in early hominid predation. Science 1976;192:441-5 
32. Marquis GS, Kolasa KM. Noodles, rice, and other non-locally-produced foods in the weaning age child's diet, Pacobamba, Peru. Ecol Food Nutr 1986;18:319-29

33. Gross DR, Underwood BA. Technological change and caloric costs: sisal agriculture in Northeastern Brazil. Am Anthropol 1971;73:725-40

34. Peters CR, Maguire B. Wild plant foods of the
Makapansgat area: a modern ecosystem analogue for Australopithecus africanus adaptations. J Hum Evol 1981;10:565-83

35. Peters CR, O'Brien EM. Early hominid plant-food niche: insights from an analysis of plant exploitation by Homo, Pan, and Papio in eastern and southern Africa. Curr Anthropol 1981;22:127-40 